\title{
PEMBUATAN MEDIA PEMBELAJARAN BACA TULIS HITUNG (CALISTUNG) BAGI MASYARAKAT DI DISTRIK ULILIN
}

\author{
Andi Saparuddin Nur ${ }^{1)}$, Tobias Nggaruaka ${ }^{2)}$, Agus Kichi Hermansyah ${ }^{3)}$ \\ Jurusan Pendidikan Matematika, FKIP Universitas Musamus ${ }^{1)}$ \\ Jurusan Pendidikan Bahasa dan Sastra Indonesia, FKIP Universitas Musamus ${ }^{2)}$ \\ Jurusan Pendidikan Guru Sekolah Dasar, FKIP Universitas Musamus ${ }^{3)}$

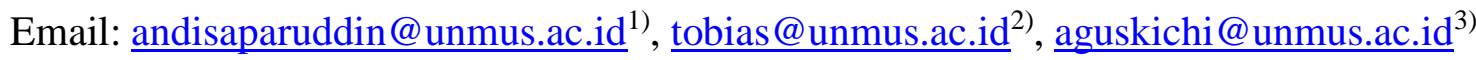

\begin{abstract}
The ability of Calistung is a basic knowledge that must be possessed by someone to be able to learn various things. Merauke Regency still has lliteracy problems related to the low ability of Calistung, especially in Baidub Village, Ulilin District. The purpose of this service is to provide training and assistance to the community in Kampung Baidub to be able to improve the ability of Calistung. Service methods used are through the stages of observation, socialization, mentoring training, monitoring and evaluation. The activity will take place in May-August 2019 with the target of the illiterate community and students of Bupul XII Elementary Inpres in Baidub Village, Ulilin District. The results of this dedication were obtained by Calistung learning media in the form of simple counting tools (abacus), picture cards, word boards, and Calistung books. The level of community participation and students participating in the activities is very high as indicated by the ability of the community Calistung and elementary students in Baidub Village to increase after the implementation of the service.
\end{abstract}

Keywords: learning media; Calistung; Ulilin District.

\begin{abstract}
Abstrak
Kemampuan Calistung merupakan pengetahuan dasar yang harus dimiliki oleh seseorang untuk dapat mempelajari berbagai hal. Kabupaten Merauke masih memiliki permasalahan penuntasan buta aksara terkait rendahnya kemampuan Calistung khususnya di Kampung Baidub, Distrik Ulilin. Tujuan dilaksanakannya pengabdian ini adalah untuk memberikan pelatihan dan pendampingan kepada masyarakat di Kampung Baidub agar mampu meningkatkan kemampuan Calistung. Metode pengabdian yang digunakan melalui tahapan observasi, sosialisasi, pelatihan pendampingan, monitoring dan evaluasi. Pelaksanaan kegiatan berlangsung pada Bulan Mei-Agustus 2019 dengan sasaran masyarakat buta aksara dan siswa SD Inpres Bupul XII di Kampung Baidub, Distrik Ulilin. Hasil pengabdian ini diperoleh media pembelajaran calistung berupa alat hitung sederhana (sempoa), kartu bergambar, papan kata, dan buku Calistung. Tingkat partsisipasi masyarakat dan siswa mengikuti kegiatan tergolong sangat tinggi yang ditunjukkan dengan kemampuan Calistung masyarakat dan siswa SD di Kampung Baidub mengalami peningkatan setelah pelaksanaan pengabdian.
\end{abstract}

Kata Kunci: Media Pembelajaran, Calistung, Distrik Ulilin

\section{PENDAHULUAN}

Pendidikan sejatinya
membebaskan dari belenggu

keterbelakangan menuju peradaban yang lebih baik. Namun kenyataannya, masih banyak masyarakat yang belum merasakan akses pendidikan. Tidak adanya akses pendidikan yang memadai memunculkan berbagai persoalan, diantaranya buta aksara. Berdasarkan hasil survey yang dilakukan oleh Badan Pusat Statistik (BPS) 2018, tingkat buta aksara paling tinggi terdapat di Provinsi Papua sebesar 28,75\% (Kusuma \& Halidi, 2018). Kondisi tersebut perlu mendapatkan perhatian khusus, terlebih lagi pemberantasan buta aksara 
diamanatkan di dalam Permendiknas Nomor 35 Tahun 2006 (Kemdiknas, 2006). Kabupaten Merauke sebagai tapal batas NKRI memiliki peranan penting dalam menjaga persatuan dan kesatuan bangsa. Peranan tersebut tidak akan mudah dilaksanakan jika masih banyak masyarakat yang berada dalam kondisi buta aksara. Sejalan dengan kebijakan pemerintah pusat, pemerintah Kabupaten Merauke juga memiliki komitmen yang kuat untuk menuntaskan buta aksara (Maya, 2018). Distrik yang menjadi fokus pemberantasan buta aksara diantaranya Distrik Okaba, Distrik Jagebob, Distrik Sota, dan Distrik Ulilin.

Distrik Ulilin merupakan distrik yang berbatasan langsung dengan Negara Papua Nugini dan Kabupaten Boven Digoel. Kampung yang mengalami tingkat buta aksara paling tinggi di Distrik Ulilin adalah Kampung Baidub. Angka melek huruf masyarakat Kampung Baidub hanya 32,6\% dengan tingkat partisipasi pendidikan dasar 29,53\%. Fasilitas pendidikan berupa sekolah sangat terbatas dengan jumlah pengajar yang terbatas pula.

Berdasarkan hasil wawancara bersama Kepala Kampung Baidub, terungkap bahwa warga memiliki keinginan kuat untuk belajar dan menyekolahkan anaknya, namun kondisi yang ada memaksa warga kurang peduli terhadap masalah pendidikan. Orang tua lebih senang jika anaknya ikut berkebun, berburu atau mencari kayu gaharu di hutan karena hasil yang diperoleh dapat langsung dirasakan dibandingkan jika harus bersekolah. Pandangan warga tersebut tidak terlepas dari kondisi ekonomi masyarakat Kampung Baidub yang sangat bergantung pada hasil perkebunan. Akan tetapi, Kepala Kampung Baidub juga menyadari pentingnya pendidikan buat masa depan warganya. Masih tingginya angka buta aksara di Kampung Baidub merupakan permasalahan yang wajib dan mendesak diselesaikan. Masyarakat Kampung Baidub sebagian besar adalah suku asli Papua yaitu Suku Yei (68,5\%) membutuhkan sarana pembelajaran membaca, menulis, dan menghitung yang interaktif dan menarik. Terlebih masyarakat yang buta aksara dan buta angka yang lebih didominasi oleh orang tua.

Penggunaan media pembelajaran membaca, menulis, dan menghitung (Calistung) sangat efektif dalam membangkitkan motivasi belajar. Media pembelajaran merupakan sarana untuk memanipulasi konsep abstraksi dari suatu informasi menjadi lebih dekat dengan pengalaman belajar sebelumnya. Sebagai contoh untuk membelajarkan konsep geometri kepada siswa akan terasa sulit jika hanya melalui objek abstrak, namun jika diilustrasikan ke dalam bentuk visual atau benda konkret maka siswa akan lebih mudah memahaminya (Nur \& Nurvitasari, 2017); (Supriyadi \& Nur, 2019). Seperti halnya dengan Calistung, siswa yang hanya mengenal konsep membaca melalui bacaan tanpa ada pengenalan huruf atau kata terlebih dahulu akan sangat sulit. Konsep perhitungan jika tidak didahului dengan pengenalan angka atau objek yang mengilustrasikan 
makna angka maka tentu tidak akan mampu menghasilkan kemampuan berhitung dengan baik.

Hasil penelitian Hermansyah (Hermansyah, 2017a) menyebutkan bahwa pemahaman anak dalam membaca lebig baik diawali dengan pengetahuannya tentang berbicara pengalaman di lingkungan sekitar. Anak perlu didekatkan dengan situasi yang nyata serta memiliki makna dalam kehidupannya. (Nur, 2016) mengungkapkan bahwa mempelajari sesuatu yang bersifat konteks (sesuai dunia nyata) lebih memudahkan siswa mengolah abstraksi informasi daripada memperolehnya melalui penjelasan guru. Membaca, menulis dan berhitung merupakan keterampilan dasar yang dibutuhkan oleh setiap manusia. Kemampuan Calistung tidak dapat langsung diberikan tanpa adanya stimulus. Menurut (Nggaruaka, 2017) seseorang dalam belajar berbahasa harus menguasai keterampilan berbicara sesuai dengan kondisi alamiahnya. Berbicara merupakan instrumen dalam merangsang kognisi seseorang membaca dan menulis. Hal tersebut disebabkan berbicara merupakan aktivitas fisik yang dilakukan secara verbal sedangkan membaca dan menulis merupakan aktivitas mental yang membutuhkan banyak abstraksi.

Target kegiatan pengabdian Calistung di Kampung Baidub adalah siswa SD dan masyarakat. Permasalahan Calistung yang dialami siswa SD dengan masyarakat Kampung Baidub adalah hal berbeda. Pendekatan yang digunakan untuk mengatasi masalah tersebut juga berbeda. Menurut (Hermansyah, 2017b) siswa SD tidak mampu membaca dan menulis disebabkan lambatnya respon verbal terakuisi menjadi simbol abstrak dalam bentuk huruf dan tanda kalimat. Meskipun siswa mampu berbicara dengan baik jika kemampuannya memahami huruf lambat maka akan berakibat pada kurangnya kemampuan membaca dan menulis. Sementara itu, (Nur \& Massang, 2016) menyebutkan bahwa kemampuan matematika siswa dipengaruhi oleh faktor keluarga dan diri sendiri. Siswa yang malas berhitung atau menganggap matematika kurang bermanfaat dalam kehidupannya dapat menjadikan seseorang tidak dapat berhitung. Sejalan dengan hal tersebut, (Nggaruaka, 2017) menemukan bahwa seseorang yang telah berada pada tahap dewasa, namun belum mampu membaca dan menulis lebih banyak dipengaruhi oleh faktor lingkungan, seperti berada di komunitas yang buta aksara sehingga tidak memiliki kepentingan untuk belajar atau merasa malu karena kondisi buta aksara seakan-akan telah menjadi identitas.

Oleh karena itu, pendekatan pemberantasan buta aksara dan buta angka di Kampung Baidub sebagai wujud nyata dukungan terhadap program Pemerintah Kabupaten Merauke yang menjadikan pendidikan dasar sebagai pilar pembangunan menjadi sangat urgen. Pendekatan yang dilakukan adalah melalui program pembuatan media pembelajaran Calistung untuk siswa SD Negeri Bupul XII dan masyarakat Kampung Baidub. 


\section{METODE PELAKSANAAN}

Kegiatan pengabdian ini dilaksanakan di Kampung Baidub Distrik Ulilin pada Bulan Mei-Agustus 2019. Metode pelaksanaan dalam kegiatan pengabdian ini dibedakan atas beberapa tahapan utama, yaitu:

a. Observasi

Proses mengumpulkan data tentang masyarakat Kampung Baidub yang masih mengalami kesulitan calistung dan siswa yang belum mampu calistung. Tim pengabdian melakukan audiensi bersama aparat kampung dan pihak sekolah dalam menganalisis kebutuhan paling mendesak warga untuk menangani masalah calistung.

b. Sosialisasi

Pada kegiatan ini, dilakukan wawancara bersama guru SD Inpres Bupul XII, aparat kampung, dan Bamuskam Kampung Baidub. Tujuan dilakukannya sosialisasi agar informasi kegiatan dapat tersampaikan ke seluruh warga dan siswa yang memerlukan pelatihan dan pendampingan pembuatan media pembelajaran Calistung.

c. Pelatihan dan pendampingan

Kegiatan pelatihan dan pendampingan dilakukan sebanyak dua tahap. Tahap pertama dilakukan pendampingan dan pelatihan bagi guru SD Inpres Bupul XII. Guru diberikan bimbingan teknis terkait penggunaan media pembelajaran Calistung di dalam kelas. Untuk mencapai tujuan pelaksanaan kegiatan, siswa ikut telibat dalam proses pendampingan pembelajaran media calistung. Tahap kedua dilakukan pelatihan dan pendampingan pada masyarakat yang masih mengalami masalah calistung bertempat di balai kampung.

d. Monitoring dan Evaluasi

Bentuk monitoring yang dilakukan adalah memastikan seluruh aparat kampung dan masyarakat mendukung terlaksananya kegiatan dengan terlibat langsung dalam pelatihan calistung. Hambatan dan kendala yang dihadapi di lapangan secepat mungkin didiskusikan dengan aparat kampung untuk memperoleh solusi terbaik. Sementara itu, bentuk evaluasi kegiatan dilakukan dengan mentabulasi jumlah masyarakat yang belum mampu calistung sebelum dan sesudah kegiatan berlangsung.

\section{HASIL DAN PEMBAHASAN}

Pelaksanaan kegiatan diawali dengan melakukan survey lapangan di Kampung Baidub Distrik Ulilin untuk menganalisis kebutuhan pengabdian pada tanggal 31 Mei 2019. Tujuan dilaksanakannya survey adalah untuk memantapkan persiapan pelatihan pembuatan media Calistung di SD Inpres Bupul XII dan Kampung Baidub. Tim pengabdian melakukan diskusi bersama kepala kampung untuk memetakan masyarakat yang masih tergolong buta aksara serta pendekatan yang tepat digunakan pada saat pelatihan. Tim juga melakukan diskusi dengan Kepala SD Inpres Bupul XII untuk memperoleh informasi tentang kesulitan guru membelajarkan siswa dan jumlah siswa yang belum mampu Calistung.

Berdasarkan hasil survey diperoleh data sebanyak 18 warga masih belum dapat melakukan Calistung, 43 warga dapat membaca dan menghitung 
namun belum dapat menulis dengan baik. Sementara itu, terdapat 30 siswa yang belum mampu membaca dan menulis dengan baik. Pertemuan dengan kepala kampung dan kepala sekolah diperoleh kesepatakan jadwal pelaksanaan kegiatan sebagai berikut:

Tabel 1. Jadwal kegiatan PkM Calistung di Kampung Baidub

\begin{tabular}{ll}
\hline \multicolumn{1}{c}{ Tanggal } & \multicolumn{1}{c}{ Kegiatan } \\
\hline 15 Juni 2019 & $\begin{array}{l}\text { Pembahasan media Calistung yang akan } \\
\text { digunakan pada kegiatan pelatihan } \\
\text { Pelaksanaan pelatihan Calistung di } \\
\text { Kampung Baidub } \\
\text { 20-21 Juni 2019 2019 }\end{array}$ \\
& $\begin{array}{l}\text { Monitoring dari rumah ke rumah terkait } \\
\text { perkembangan kemampuan Calistung }\end{array}$ \\
3-4 Agustus 2019 & Evaluasi kegiatan dan tindak lanjut \\
\hline
\end{tabular}

Berdasarkan diskusi bersama kepala kampung diperoleh kesepakatan terkait media Calistung yang akan digunakan merupakan alat-alat sederhana dan mudah dijumpai di lingkugan sekitar seperti kayu, plastik, tripleks, dan kertas. Adapun media Calistung yang digunakan adalah: sempoa, kartu huruf, kartu bergambar, buku calistung, kotak operasi hitung bilangan negatif, dan media tulis kata.

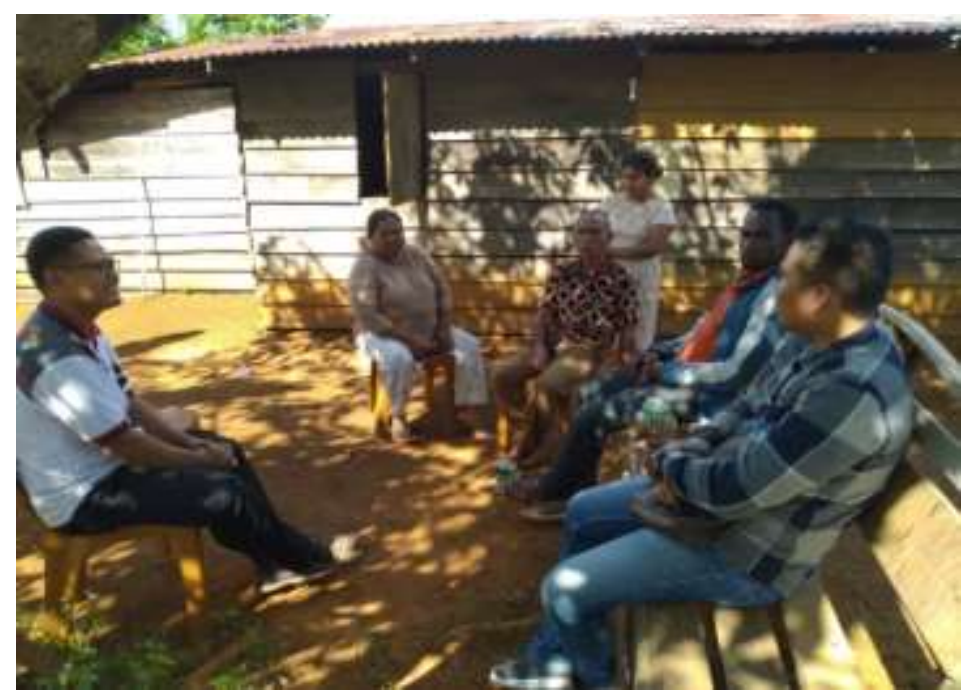

\section{Gambar 1. Pertemuan dengan kepala kampung}

Proses pembuatan media Calistung melibatkan mahasiswa semester akhir dalam mengembangkan serta membuat konsep alat peraga yang akan digunakan. Bentuk konkrit keterlibatan mahasiswa dalam kegiatan PkM ini adalah dengan ikut mendiskusikan perangkat calistung serta terjun langsung ke lapangan bersama tim. Konsolidasi untuk pemantapan waktu pelatihan 
didiskusikan bersama dan diperoleh kesepakatan pada tanggal 22 Juni 2019 tim PkM melaksanakan pengabdian di
SD Inpres Bupul XII dan tanggal 23 Juni 2019 di Balai Kampung Baidub.

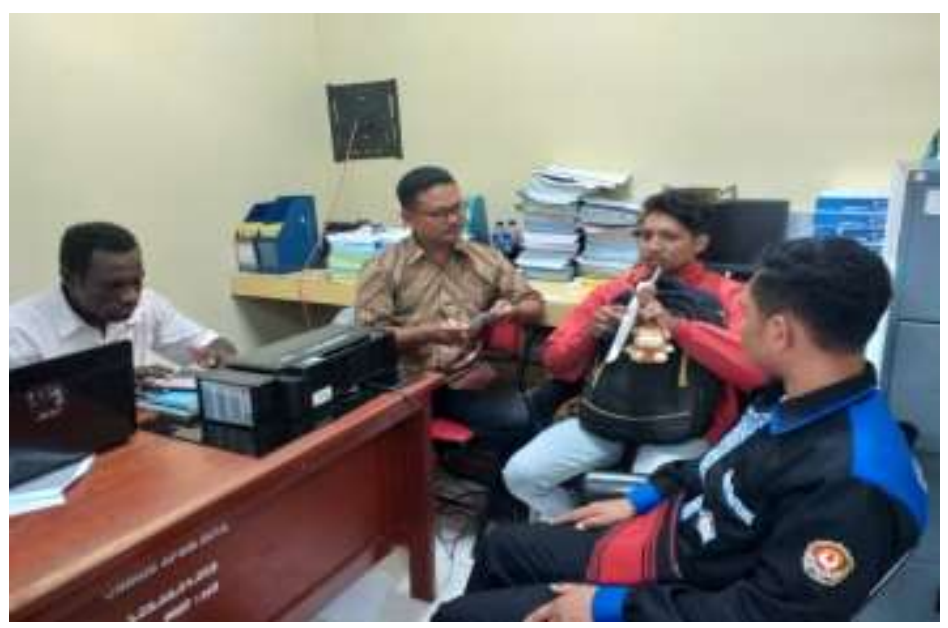

\section{Gambar 2. Konsolidasi tim untuk kegiatan pelatihan Calistung}

Pelaksanaan pelatihan Calistung pada tanggal 22 Juni 2019 berlangsung di SD Inpres Bupul XII diikuti oleh 46 siswa dan 4 guru. Kegiatan diawali dengan sambutan dari ketua tim PkM dan Kepala Sekolah beserta perkenalan tim dengan guru dan siswa. Selanjutnya, kegiatan dipusatkan di ruang kelas dengan membagi siswa ke dalam tingkatan kelas tinggi dan kelas rendah. Pada kegiatan simulasi media Calistung, guru ikut memperhatikan pengarahan dari tim PkM. Siswa menunjukkan sikap antusias yang tinggi dalam mengikuti kegiatan, ditandai dengan banyaknya siswa yang ingin tampil di depan kelas. Pada sela-sela kegiatan, guru juga ikut bertanya terkait dengan teknik merakit media yang digunakan, khususnya pada media berhitung seperti sempoa. Penggunaan media Calistung yang mudah dan murah menjadi daya tarik bagi guru mengikuti kegiatan PkM.

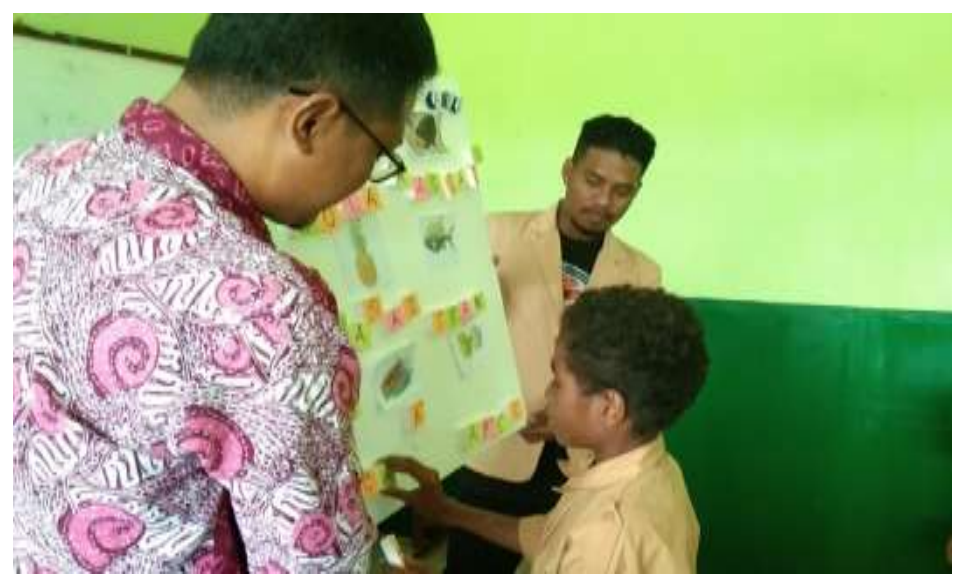

Gambar 3. Siswa belajar merangkai huruf menggunakan media kartu bergambar 
Kepala SD Inpres Bupul XII memberikan apresiasi kepada tim yang telah memberikan pelatihan pembuatan media Calistung bagi siswa dan guru. Kegiatan yang dilaksanakan di SD Inpres Bupul XII merupakan langkah nyata kehadiran perguruan tinggi yang sangat dibutuhkan oleh sekolah di daerah perbatasan dan terpencil.

Kegiatan pelatihan pada tanggal 23 Juni 2019 dipusatkan di Balai Kampung Baidub dengan mengundang masyarakat serta prajurit TNI satuan tugas penjaga perbatasan (Satgas Pamtas RI-PNG). Kegiatan di balai kampung difokuskan pada keterlibatan masyarakat dalam belajar calistung secara mandiri agar dapat membantu anak-anak mengembangkan sarana belajar yang efektif di rumah. Pelaksanaan kegiatan diawali dengan pemaparan singkat dari tim pengabdian tentang media Calistung yang dapat dikembangkan menggunakan peralatan sederhana yang terdapat di lingkungan sekitar.

Minat masyarakat, khususnya yang masih mengalami kendala calistung tergolong tinggi. Sebanyak 74 warga yang mengikuti kegiatan pelatihan $62 \%$ diantaranya masih memerlukan bimbingan terkait masalah Calistung. Masyarakat dengan kemampuan Calistung kategori rendah merupakan warga lanjut usia dengan usia 50-80 tahun sedangkan masyarakat dengan kemampuan Calistung kategori sedang merupakan penduduk lokal yang sebagian besar adalah hasil perkawinan campuran lintas negara.

Kegiatan pelatihan Calistung di balai kampung mendapatkan respon positif dari berbagai pihak termasuk prajurit TNI Satgas Pamtas di Kampung Baidub. Bentuk perhatian yang diberikan terhadap kelancaran kegiatan adalah dengan mengamankan seluruh rangkaian kegiatan.

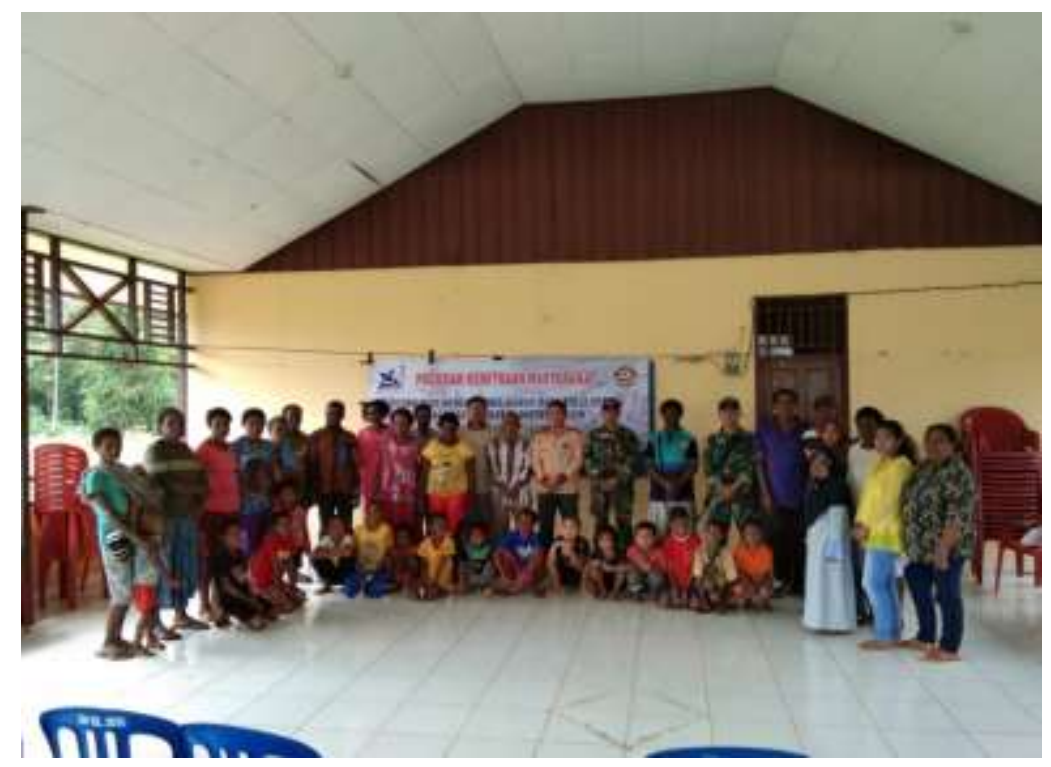

Gambar 4. Peserta pelatihan Calistung di balai kampung 
Pelaksanaan monitoring sebagai upaya keberlanjutan kegiatan pelatihan dilaksanakan secara door to door. Tim pengabdian memastikan seluruh hasil kegiatan dapat diterapkan oleh masyarakat dan guru sehingga mempercepat proses penuntasan buta aksara di Kampung Baidub. Pelaksanaan monitoring dilaksanakan tim bersama kepala kampung mendatangi rumah warga dan menanyakan kemajuan yang telah diperoleh melalui penggunaan media Calistung. Masyarakat memberikan respon yang sangat baik dengan menunjukkan kemampuan Calistung kepada tim. Kepala kampung juga ikut mendata masyarakat sebelum dan sesudah pelaksanaan kegiatan pengabdian kemampuan Calistungnya mengalami peningkatan. Berikut hasil peningkatan kemampuan Calistung yang dialami oleh masyarakat Kampung Baidub setelah pelaksanaan kegiatan.

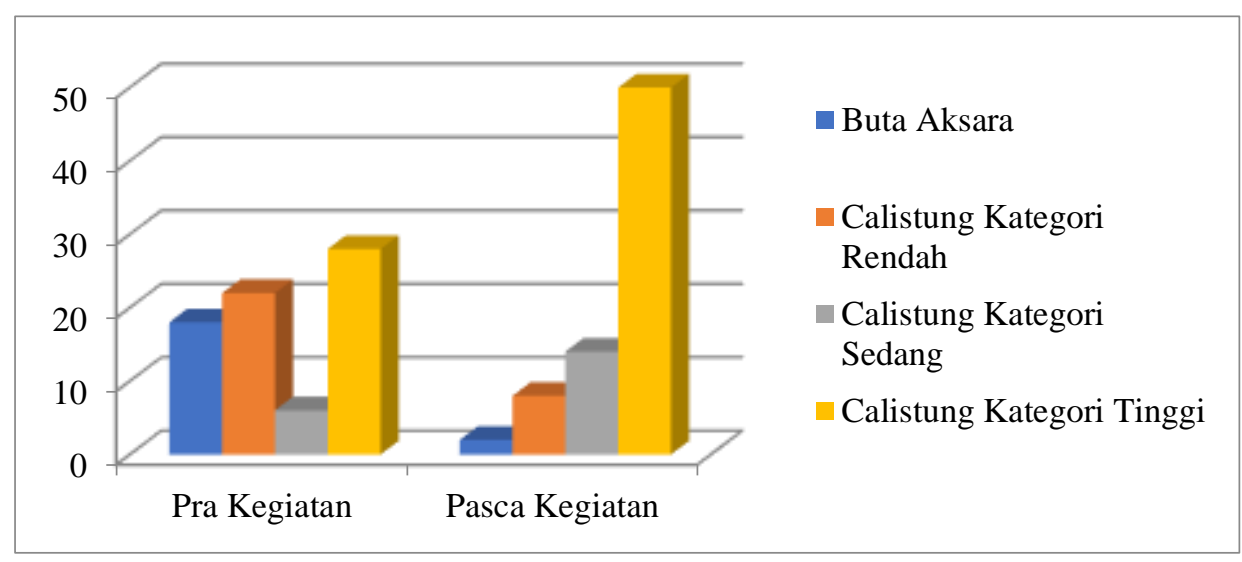

Gambar 5. Peningkatan Kemampuan Calistung Masyarakat Kampung Baidub

Monitoring juga dilaksanakan di SD Inpres Bupul XII terkait penggunaan media pembelajaran Calistung oleh siswa. Berdasarkan informasi yang diberikan oleh guru, diperoleh data peningkatan kemampuan Calistung siswa setelah kegiatan seperti pada gambar 6.

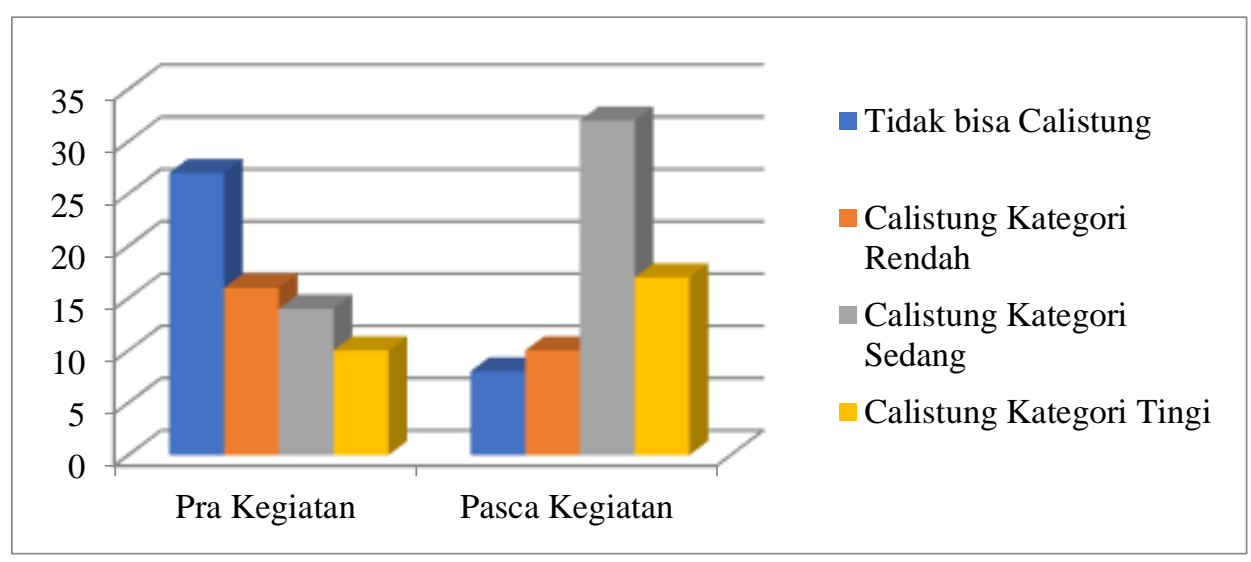

Gambar 6. Peningkatan Kemampuan Calistung Siswa SD Inpres Bupul XII 
Peningkatan kemampuan Calistung yang diperoleh setelah pelaksanaan pelatihan dan pendampingan tergolong cukup tinggi, khususnya pada masyarakat di Kampung Baidub. Tercatat masyarakat yang telah mampu Calistung kategori tinggi menjadi dua kali lipat dari sebelum pelaksanaan kegiatan. Masyarakat yang masih buta aksara sebelumnya berjumlah 18 orang menjadi tersisa 2 orang setelah dilaksanakan kegiatan pelatihan. Masyarakat yang belum mampu Calistung sebanyak 2 orang tersebut merupakan warga usia lanjut dengan keterbatasan penglihatan. Berdasarkan informasi dari kepala kampung, masyarakat sangat antusias dalam mempelajari Calistung baik yang difasilitasi oleh aparat kampung maupun belajar mandiri bersama anak-anak di rumah. Dorongan belajar yang mulai tumbuh merupakan awal yang baik bagi pemberantasan buta aksara di Kampung Baidub, Distrik Ulilin.

Sementara itu, kemampuan Calistung di SD Inpres Bupul XII mulai menunjukkan hasil yang menggembirakan. Sebanyak 26 siswa yang sebelum pelaksanaan pelatihan belum dapat Calistung berkurang menjadi 7 siswa dan terus menunjukkan kemajuan untuk dapat membaca dengan lancar. Hampir setengah jumlah siswa telah berada pada kemampuan Calistung kategori sedang yang sebelum pelaksanaan kegiatan lebih didominasi siswa belum dapat Calistung. Peningkatan yang dialami siswa tidak terlepas dari peran aktif guru dalam mengembangkan media pembelajaran
Calistung. Kepala sekolah dan guru SD Inpres Bupul XII sangat mengapreasiasi kegiatan pelatihan dan pendampingan yang telah dilaksanakan oleh tim pengabdian sehingga mampu menghasilkan suatu media pembelajaran yang dapat membantu siswa meningkatkan kemampuan Calistung.

Pendidikan merupakan ujung tombak dari perubahan kondisi suatu bangsa menuju ke arah yang lebih baik dan bermartabat. Masyarakat yang telah memahami arti penting pendidikan sejatinya telah menemukan puing-puing peradaban dan memiliki harapan untuk membangun masa depan yang lebih cerah. Pelatihan pembuatan media pembelajaran Calistung yang dilaksanakan di Kampung Baidub Distrik Ulilin merupakan langkah awal untuk memastikan tidak terdapat lagi ruang gelap ketertinggalan pendidikan di pelosok negeri. Berkembangnya pengetahuan dan pemahaman masyarakat di Kampung Baidub terkait Calistung merupakan harapan untuk lahirnya generasi yang terbebas dari buta aksara.

\section{PENUTUP}

Pelaksanaan kegiatan pelatihan pembuatan media Calistung di Distrik Ulilin menghasilkan perangkat media Calistung berupa sempoa, kartu bergambar, papan kata, dan buku Calistung. Media yang digunakan selanjutnya dikembangkan sendiri oleh masyarakat dan guru untuk keperluan pembelajaran secara mandiri. Penggunaan media pembelajaran Calistung dapat membantu masyarakat 
dan siswa memahami proses membaca, menulis dan berhitung secara lebih cepat.

Adapun saran untuk keberlanjutan program penuntasan buta aksara adalah perlu adanya perhatian bagi masyarakat yang memiliki disabilitas serta usia lanjut. Pengembangan media Calistung hendaknya dapat membantu masyarakat yang memiliki berbagai keterbatasan fisik.

\section{UCAPAN TERIMA KASIH}

Tim pengabdian mengucapkan terima kasih kepada DRPM Kementerian Riset, Teknologi, dan Pendidikan Tinggi yang telah mendanai kegiatan ini melalui Skema Pengabdian Kemitraan Masyarakat (PkM) Tahun Anggaran 2019.

\section{DAFTAR PUSTAKA}

Hermansyah, A. K. (2017a). Desain Pembelajaran Berbicara untuk https://www.suara.com/health/201 8/09/04/140511/kemendikbudtingkat-buta-aksara-di-indonesiaturun-drastis

Maya. (2018). Pemda Merauke Fokus Pemberantas Buta Aksara, Hari Aksara Internasional. Retrieved October 8, 2018, from https://portal.merauke.go.id/news/ 3659/pemda-merauke-fokuspemberantas-buta-aksara-hariaksara-internasional.html

Nggaruaka, T. (2017). Implementasi Teknik Retrival dalam Pembelajaran Bahasa Indonesia di SMP. In Seminar Nasional Kependidikan Fakultas Keguruan dan Ilmu Pendidikan (pp. 88-96).
Mengenalkan Nilai-Nilai Moral Kemanusiaan melalui Bermain Peran. Edukasi, 4(1).

Hermansyah, A. K. (2017b). Nilai-Nilai Kemanusiaan dalam Buku 100 Cerita Anak Pilihan dan Kesesuaiannya sebagai Bahan Pembelajaran Sastra di Indonesia. Al Ibtida, 4(1).

Kemdiknas. Pedoman Pelaksanaan Gerakan Nasional Percepatan Penuntasan Wajib Belajar Pendidikan Dasar Sembilan Tahun dan Pemberantasan Buta Aksara, Pub. L. No. Permendiknas No.35 Tahun 2006 (2006). Indonesia.

Kusuma, A. I., \& Halidi, R. (2018). Kemendikbud: Tingkat Buta Aksara di Indonesia Turun Drastis. Retrieved February 22, 2019, from Merauke: Universitas Musamus.

Nur, A. S. (2016). Pengaruh Penerapan Pembelajaran Kontekstual Setting Kooperatif Tipe Team Games Tournament (TGT) Terhadap Kemampuan Pemecahan Masalah Matematika. Aksioma Jurnal Pendidikan Matematika, 5(1), 1525.

Nur, A. S., \& Massang, B. (2016). Pengaruh Pola Asuh Orang Tua , Konsep Diri , dan Motivasi Berprestasi terhadap Prestasi Belajar Matematika Siswa Kelas IX SMP Negeri di kota Merauke, 2(2), 89-96.

Nur, A. S., \& Nurvitasari, E. (2017). Geometry Skill Analysis In 
Problem Solving Reviewed From The Difference of Cognitive Style Students Junior High School. Journal of Educational Science and Technology, 3(3).
Supriyadi, \& Nur, A. S. (2019). Pembuatan Media Pembelajaran Matematika dan IPA yang Terintegrasi dengan Nilai Budaya Lokal Pada SMP YPK Tomer. Sarwahita, 16(1), 56-67. 